\section{AUT exam boycott enters week 11}

\section{London}

THE end of the 10-week-old lecturers' boycott of British university examinations is no closer after weeks of intense negotiations between the Association of University Teachers (AUT), the Committee of Vice-Chancellors and Principals (CVCP) and the government. If the action continues, final year students may not be awarded classified degrees, and universities fear students may take legal action against them. Already mid-term examinations have been cancelled and summer papers are not being prepared.

The CVCP is meeting this week to discuss how to minimize the effects of the strike on students. Vice-chancellors could decide to award unclassifed degrees based on tutors' reports or to ask students to sit examinations after the summer, at the time when re-sits are usually taken. Meanwhile, they are hoping that AUT members will disagree with the council, the policy-making body of the union, which last week rejected the CVCP's latest offer of a pay rise. Members will be balloted in April on whether to accept the council's decision.

The offer of an increase of 6.5 per cent for 1989-90 was made after the universities received an undisclosed sum from the government, on condition that the strike is ended. The CVCP had asked for $£ 187$ million but received "a lot less than that", according to a spokesman. The union is certain that the universities can finance a larger pay increase, though Sir Mark Richmond, chairman of the CVCP, denies this, saying that the latest offer is final, and that to offer any more would bankrupt some universities.

Christine McGourty

THINK-TANK

\section{Berlin academy fights closure threats}

\section{Munich}

THE new left-wing government in West Berlin plans to close the 'Academy of Sciences and Technology in Berlin'. The academy was founded in 1987 by the thenconservative government as an interdisciplinary think-tank especially concerned with problems of technology and society. The Greens and Social Democrats now in power denounced the academy as an "old men's debating club" (see Nature 329, 659; 1987). The academy's research fields include solar energy, ageing and society, and the impact on German science of the exodus of researchers from Berlin in 1933. It had a 1988 budget of DM8 million, mostly provided by the West Berlin government.

The academy will fight for its existence. Spokesman Eberhard Vogt said that the "last word" had not yet been spoken about the future of the academy.

Steven Dickman

\title{
Independent agency for UK
}

\section{London}

BRITAIN's main defence research institutes are to be grouped together in an independent defence research agency in order to loosen their ties with the Ministry of Defence, their main customer.

At first the agency will be made up of four institutes: the Admiralty Research Establishment, the Royal Aerospace Establishment, the Royal Armament Research and Development Establishment and the Royal Signals and Radar Establishment.

The Aeroplane and Armament Experimental Establishment is also being considered, but the Chemical Defence Establishment (CDE) at Porton Down will not be part of the agency. A review carried out last year by a study team for the Ministry of Defence (MoD) said that, because of the political and public sensitivity about the work carried out there, and because of the role of the establishment in providing support to government on international arms control, the CDE should be excluded from the agency.

The agency will be expected to increase the work at the institutes carried out for industry, and will have to compete with industry for some contracts for the MoD. There is also likely to be a reduction in staff and in the number of sites. More than
12,000 staff work in the institutes at over 100 sites, most of which are in South-East England where land sales would be remunerative.

There are still many uncertainties surrounding the form of the new agency. A team has been set up to plan in detail the changes before the agency is formed in 1991. It could take the form of a trading fund within or outside the civil service, or it could be a government-owned public limited company. Full privatization has been ruled out.

Manpower is one of the important problems to be tackled. A serious shortfall in recruitment of young graduates, especially in electronics, computing and mathematics. combined with a high rate of resignations among the youngest and brightest of researchers, has led to a shortage of highcalibre staff. The defence research study team said that this could be solved by the introduction of more short-term contracts and by giving the agency more independence to fix pay scales, now set at civil servant rates.

The study team also stressed that in a new agency mechanisms must be put in place to safeguard strategic research, which could be neglected in the commercial climate.

Christine McGourty

\section{US SALARIES}

\section{Less pay means empty jobs}

\section{Atlanta}

THE AIDS epidemic may have helped the budget of the US Centers for Disease Control (CDC) to multiply to more than $\$ 1,000$ million a year in the the past six years, but the hefty increase has not meant salary rises for its researchers.

Instead, the agency, the front-line of defence against epidemics in the United States which also helps to staunch outbreaks of disease around the world, is suffering from the same problems as the rest of the US government's research enterprise - those of hiring the best and the brightest talent.

Earlier this year, CDC's largest research centre, the 1,000-staff Center for Infectious Diseases, was forced to cast its net outside the United States to fill one of its top posts. Fred Murphy, director of the centre, made the unusual move of hiring one of Britain's top virologists, Brian Mahy, away from his directorship of the Agriculture and Food Research Council's Pirbright Laboratory. Five US scientists offered the job had turned it down because the $\$ 75,000$ salary was too low.

Mahy says he was not actively looking for a job when Murphy came knocking on his door, but recent shake-ups in the organization of British veterinary science (see
Nature 338, 191; 1989) made moving to the United States more attractive. He says he considered the CDC post an advancement and it offered him a 25 per cent raise in salary. Several other Pirbright scientists left with Mahy to work at CDC.

CDC's Murphy says he spends much of his time looking for prospective employees, and that it takes 6-12 months to find the right people for executive-level positions within his office and as directors for his centre's 12 divisions. He has had to fill seven "very senior positions" within the past year and half.

The most pressing vacancy at CDC is a replacement for CDC director James $\mathrm{O}$. Mason, who has been chosen by the Bush administration to be the US Assistant Secretary of Health, in charge of the Public Health Service which oversees both CDC and the National Institutes of Health. While Mason or the new Secretary of Health and Human Services, Louis Sullivan, could turn the CDC directorship into a political appointment. George Hardy, acting deputy director of CDC, predicts that the job will be filled by a search committee, a process which could take several months. Mason is sure to take an active interest in selecting the new CDC director.

Carol Ezzell 